\title{
Poppy (Papaver somniferum L.) Intercropping with Spring Barley and with White Clover: Benefits and Competitive Effects
}

\author{
Katharina Luhmer ${ }^{1, *(\mathbb{D}}$, Hanna Blum ${ }^{1}$, Thorsten Kraska ${ }^{1,2} \mathbb{(}$, Thomas Döring ${ }^{3}\left(\mathbb{D}\right.$ and Ralf Pude ${ }^{1,4}$ \\ 1 Institute of Crop Science and Resource Conservation-Renewable Resources, University of Bonn, \\ Klein-Altendorf 2, 53359 Rheinbach, Germany; hblum@uni-bonn.de (H.B.); kraska@uni-bonn.de (T.K.); \\ r.pude@uni-bonn.de (R.P.) \\ 2 Institute of Crop Science and Resource Conservation-Horticultural Science, University of Bonn, \\ Auf dem Hügel 6, 53121 Bonn, Germany \\ 3 Institute of Crop Science and Resource Conservation-Agroecology and Organic Farming, \\ University of Bonn, Auf dem Hügel 6, 53121 Bonn, Germany; tdoering@uni-bonn.de \\ 4 Field Lab Campus Klein-Altendorf, University of Bonn, Klein-Altendorf 2, 53359 Rheinbach, Germany \\ * Correspondence: kluhmer@uni-bonn.de; Tel.: +49-22-259-996-311
}

Citation: Luhmer, K.; Blum, H.; Kraska, T.; Döring, T.; Pude, R. Poppy (Papaver somniferum L.) Intercropping with Spring Barley and with White Clover: Benefits and Competitive Effects. Agronomy 2021, 11, 948. https://doi.org/10.3390/ agronomy11050948

Academic Editor: Eleni Tani

Received: 15 April 2021

Accepted: 6 May 2021

Published: 11 May 2021

Publisher's Note: MDPI stays neutral with regard to jurisdictional claims in published maps and institutional affiliations.

Copyright: (c) 2021 by the authors. Licensee MDPI, Basel, Switzerland. This article is an open access article distributed under the terms and conditions of the Creative Commons Attribution (CC BY) license (https:/ / creativecommons.org/licenses/by/ $4.0 /)$.

\begin{abstract}
Poppy seed production is susceptible to abiotic and biotic stress and weed infestation, which introduces the risk of total crop failure. For the purpose of risk minimization, poppy was grown in additive intercropping systems with early and late sown white clover and spring barley sown at three different densities in a three year field trial to assess their roles in poppy cropping while adding ecological benefits to the crop rotation. Poppy yielded between 798.7 and $1293.1 \mathrm{~kg} \mathrm{ha}^{-1}$, with no significant yield effects of intercropping with white clover, compared to poppy sole-cropping. Dry matter, height, leaf area index and $\mathrm{C} / \mathrm{N}$ ratio of the poppy plants were not significantly impacted by the clover intercrop either, independent on its sowing date. Higher poppy yields (695.6-918.8 $\mathrm{kg} \mathrm{ha}^{-1}$ ) and LERs (1.11-1.84) in the poppy-barley intercrop were achieved in 2018 and 2020 compared to 2019 ( $\leq 361.5 \mathrm{~kg} \mathrm{ha}^{-1}$, LER $\left.\leq 0.99\right)$, mainly due to differences in seeding dates, precipitation and nutrient availability. Therefore, previous seeding of poppy limits competition when intercropped with barley while white clover and poppy can be sown at the same time. The effect of barley seeding densities on the intercrop performance was small as was the influence of intercropping on weed cover, number and biomass. The weed regulating effect needs to be further examined, however, we conclude that intercropping of poppy is a promising strategy for its cultivation, in terms of minimizing the risk of total yield losses when precisely managed.
\end{abstract}

Keywords: Papaver somniferum L.; mixed cropping; polyculture; weeds; competition

\section{Introduction}

Sustainable farming systems are based on diverse production strategies to produce high-quality food under the premise of minimizing resource consumption. While the goal of modern agriculture to increase productivity in monocultures often contrasts with the concept of sustainability [1,2], the long-term benefits of diverse cropping systems have been demonstrated repeatedly [3-7]. Maintaining soil fertility, enhancing weed suppression and decreasing the risk of yield losses may be achieved by increasing in-field crop diversity [3,8]. Relying on a broader range of crops can further promote flexibility towards environmental disturbances which is particularly important in a changing climate [8].

One strategy of diversification in agriculture is intercropping [1,5], i.e., the simultaneous growing of two or more crops on the same field at the same time $[1,2,4,9]$. Potential benefits of intercropping include weed suppression and ecological pest and disease control, both of which are of particular importance in organic farming [1,5,8]. Intercropping may also lead to more efficient resource use, mostly because of temporal or spatial differences in resource use by the individual crops. This resource partitioning among intercrops, along 
with other mechanisms, can increase the overall yield from a given area $[1-4,8-11]$. Thus, a functioning intercrop is based on partners that occupy complementary niches $[2,11,12]$. However, competitiveness of the combined crops is strongly influenced by the environment and cultivation practices like time of planting, fertilization and pest control [7]. As crop-crop interactions may change from one cropping environment to another, choosing the right partners and managing an intercrop is difficult [1]. This is particularly true for intercropping poppy, due to a lack of experimental studies.

Apart from possible yield advantages, intercrops can provide additional benefits like enhanced weed suppression compared to single crops [8], especially in additive intercrops where overall crop density is higher than in the respective monocultures. There are several studies proving a weed suppressing effect of crops grown as intercrops, most of them combining cereals with legumes [8,13-17]. While the exact mechanisms of weed regulation by intercrops are still debated, competition for resources such as light is altered when another crop is introduced to a system [3,4,8]. Further, competition for nitrogen influences the intercrop performance as crops differ in nitrogen requirements and their dependence on soil nitrogen. This also applies to competition for nitrogen with weeds. For example legumes leave more soil $\mathrm{N}$ to be used by intercrops or weeds than non-nitrogen-fixating plants like barley [18]. That is why total nitrogen uptake of an intercrop can be higher than in the respective sole crops and nitrogen acquisition of weeds will be limited [19].

Resource partitioning and facilitation are the two main principles that usually contribute to enhanced weed suppression in intercrops $[4,11]$. While not all trials confirmed an advantage of intercropping in terms of weed regulation [17,20], Liebmann and Dyck (1993) considered most intercropping designs successful compared to the weed suppressing effect of at least one of the sole crops [3].

Weed management is a crucial point in poppy cultivation. Due to slow initial growth resulting in a long phase with slow biomass build up, the suppression of poppy plants by weeds is frequently observed [21-24]. Secondly, late weed infestation can become problematic when green parts of tall weeds like Chenopodium album $\mathrm{L}$. are harvested together with the poppy capsules [23]. It can make post-harvest drying necessary and a separation of C. album seeds from poppy seeds is difficult due to similar color and size [23]. Suppression by intercropping might not always be complete or more effective than herbicide use but could also be of economic interest as costs for herbicides, mechanical or manual weeding are reduced [3]. Therefore, an intercrop design may be chosen to increase soil cover during the whole cropping period. An increased soil cover by intercropping further minimizes soil erosion, evaporation and allows for allelopathic effects between plants [3,25]. Intercropping can also be a measure to reduce total crop failure $[5,26]$. In the case of poppy, cultivation is often prone to failure due to its high requirements for seedbed preparation and crop management (weed regulation) in early development, making an intercropping experiment particularly worth looking into.

However, to our knowledge, there are no recently published studies on intercropping including poppy. Poppy belongs to a plant family that is otherwise not represented in European farming systems, which creates opportunities to integrate poppy into many crop rotations [22]. Therefore, facilitating poppy cultivation by implementing it in an intercrop can promote its cultivation and contribute to general diversification of cropping systems using minor crop species.

Liebmann and Dyck (1993) [3] define two categories of intercrops, one of them focusing on the main crop where the other crop is added for insurance against crop failure, minor economic uses, erosion control, soil fertility improvement and weed control. This contrasts with a system where both crops are of equal interest to the farmer. The first design applies better to our approach where poppy is the focus crop and spring barley and white clover were chosen as supporting crops. Both companion crops should primarily increase soil cover while not reducing poppy growth and yields. While barley may achieve an extra yield, thus reducing the risk of total crop failure, clover provides an external nitrogen source through nitrogen fixation, thereby limiting competition for soil $\mathrm{N}[16,27]$ and improving 
soil conditions for the following crop. A weed suppressing effect was presumed for all intercropping treatments due to increased plant density and ground cover.

Here we aimed to test if intercropping of poppy with both barley and white clover improves poppy cultivation by decreasing the risk of total yield losses and adding ecological benefits at the same time. Secondly, we aimed to discover key factors determining poppy intercrop performance and competitiveness by testing different seeding densities of barley and two sowing dates of white clover regarding plant growth, yield formation and weed suppression.

\section{Materials and Methods}

\subsection{Site Description}

Field trials were carried out at the site of Campus Klein-Altendorf (CKA), University of Bonn, for three consecutive years (2018-2020). The CKA is conventionally farmed but the field trial was predominantly managed under organic principles. This mostly means that the use of pesticides was avoided in these trials, but it must be acknowledged that weed occurrence would probably have been different on long-term organically managed soils. The experimental farm is located on the main terrace area of the Lower Rhine valley. Average annual precipitation and temperature are $603 \mathrm{~mm}$ and $9.4{ }^{\circ} \mathrm{C}$, respectively, and the vegetation period lasts 165-170 days. Precipitation and temperature during the trial periods of 2018-2020 were measured at the CKA weather station (Table 1). The main difference between years was that precipitation in 2018 and 2020 was almost always below the long term average while rainfall in 2019 was high, especially in the months of March, May and July.

Table 1. Mean temperature $\left({ }^{\circ} \mathrm{C}\right)$ and precipitation $(\mathrm{mm})$ for March to August at Campus KleinAltendorf (Germany) in the experimental years compared to the long-term average (1956-2019).

\begin{tabular}{ccccccccc}
\hline Month & \multicolumn{4}{c}{ Temperature $\left({ }^{\circ} \mathbf{C}\right)$} \\
\hline & $\mathbf{2 0 1 8}$ & $\mathbf{2 0 1 9}$ & $\mathbf{2 0 2 0}$ & $\mathbf{A v} \mathbf{~}^{\mathbf{1}}$ & $\mathbf{2 0 1 8}$ & $\mathbf{2 0 1 9}$ & $\mathbf{2 0 2 0}$ & $\mathbf{A v}^{\mathbf{1}}$ \\
\hline March & 4.3 & 7.4 & 6.7 & 5.5 & 35.8 & 63.9 & 39.0 & 40.5 \\
April & 12.9 & 10.0 & 11.7 & 8.7 & 40.8 & 26.7 & 5.4 & 43.3 \\
May & 16.1 & 11.3 & 13.1 & 12.8 & 34.9 & 75.8 & 18.1 & 57.5 \\
June & 18.0 & 19.7 & 17.3 & 15.7 & 47.1 & 25.5 & 66.3 & 65.7 \\
July & 21.4 & 19.5 & 18.4 & 17.4 & 22.8 & 55.0 & 27.1 & 65.8 \\
August & 20.2 & 19.4 & 21.0 & 17.0 & 19.7 & 69.6 & 83.6 & 67.2 \\
\hline
\end{tabular}

${ }^{1}$ Long-term average from 1956-2019.

The soil type at CKA is a highly fertile luvisol. Soil nutrient levels in 0-30 $\mathrm{cm}$ depth were determined at the beginning of each growing period (Table 2). Samples were collected at five points per site and merged into a mixed sample. In 2019 and 2020 organic nitrogen fertilizer as fine grained horn meal ( $0-1 \mathrm{~mm}, 13 \%$ organically bound $\mathrm{N})$ at $30 \mathrm{~kg} \mathrm{~N} \mathrm{ha}^{-1}$ was manually applied on all plots a few days after sowing. Preceding crops were winter wheat (2017 and 2018) and spring barley (2019).

Table 2. Summary of physical and chemical soil properties of the experimental site for the top $30 \mathrm{~cm}$ in experimental years.

\begin{tabular}{|c|c|c|c|c|}
\hline Year & $\mathrm{pH}$ & $P \mathrm{mg} / 100 \mathrm{~g}$ & $\mathrm{~K} \mathrm{mg/100} \mathrm{g}$ & $\mathrm{Mg} \mathrm{mg/100} \mathrm{g}$ \\
\hline 2018 & 7.0 & 19 & 10 & 7.8 \\
\hline 2019 & 6.5 & 14 & 15 & 12.1 \\
\hline 2020 & 6.9 & 22 & 16 & 8.2 \\
\hline
\end{tabular}

\subsection{Experimental Design}

The trial was a complete randomized block design with four blocks arranged next to each other, each block comprising the eleven treatments so that each treatment was 
replicated four times. The plot size of each treatment was $3 \mathrm{~m} \times 10 \mathrm{~m}$. The main crop was the spring-sown poppy variety "Viola" (Zeno Projekte, Austria) that was tested in additive intercropping with white clover cultivar (cv.) "SW Hebe" (Camena Samen, Lauenau, Germany) and spring barley cv. "Laureate" (Syngenta, Maintal, Germany).

To explore if a delayed sowing of clover increases the compatibility of both crops, two different seeding dates of clover were tested in combination with poppy. Concerning barley, intercropping effects on poppy and barley yield formation were of primary importance resulting in the testing of three different seeding densities of barley for assessing competition effects. The seeding density of poppy remained the same in all treatments and throughout all years. Each crop was also grown as a sole crop for comparison. In total, 11 treatments were tested (Table 3).

Table 3. Treatments of the poppy intercropping trial.

\begin{tabular}{|c|c|}
\hline Code & Treatment \\
\hline $\mathrm{P}$ & Poppy \\
\hline $\mathrm{B} 1 *$ & Barley at 135 seeds $\mathrm{m}^{-2}$ \\
\hline B2 & Barley at 270 seeds $\mathrm{m}^{-2}$ \\
\hline B3 & Barley at 450 seeds $\mathrm{m}^{-2}$ \\
\hline C1 & Clover sown early \\
\hline $\mathrm{C} 2$ & Clover sown late \\
\hline PB1 * & Poppy + barley at 135 seeds $\mathrm{m}^{-2}$ \\
\hline PB2 & Poppy + barley at 270 seeds $\mathrm{m}^{-2}$ \\
\hline PB3 & Poppy + barley at 450 seeds $\mathrm{m}^{-2}$ \\
\hline PC1 & Poppy + clover sown early \\
\hline PC2 & Poppy + clover sown late \\
\hline
\end{tabular}

ॠ Only in 2019\& 2020 .

Seeding and harvest dates are summarized in Table 4. Only the grains of barley and poppy seeds were harvested while clover was grown as green manure. Poppy seeds were sown with a precision air seeder for small seeds at $1.1 \mathrm{~kg} \mathrm{ha}^{-1}$ in both the intercrops and the sole crop. This resulted in poppy plant densities after seed emergence of $202( \pm 33 ; 2018)$, $210( \pm 28 ; 2019)$ and $69( \pm 44 ; 2020)$ plants $\mathrm{m}^{-2}$ respectively. Row spacing between poppy rows was $50 \mathrm{~cm}(2018)$ and $45 \mathrm{~cm}(2019,2020)$ so that every plot contained 6 poppy rows. Row spacing was changed to improve compatibility of the sowing machine and tractor to avoid effects on plant growth at the side of the plots. Clover and barley seeds were spread between poppy rows with a mechanical seed drilling machine with $11 \mathrm{~cm}$ row spacing. The seeding shares that would interfere with poppy rows were lifted. Therefore, intercropped plots contained 6 poppy rows and 16 rows of the respective intercrop (Figure S1). Clover was sown at $5.3 \mathrm{~kg} \mathrm{ha}^{-1}\left(145 \pm 25\right.$ plants m $\mathrm{m}^{-2}$ after emergence) and barley at 135,270 and 450 germinable seeds $\mathrm{m}^{-2}$ (Table 3 ). Sole crops consisted of the same row pattern but with the intercropping partner left out.

Table 4. The seeding dates of poppy, clover and barley in the intercrop experiment 2018-2020 at Campus Klein-Altendorf, Germany.

\begin{tabular}{ccccccc}
\hline Cultivar & \multicolumn{2}{c}{2018} & \multicolumn{2}{c}{ 2019 } & \multicolumn{2}{c}{ 2020 } \\
& Seeding & Harvest & Seeding & Harvest & Seeding & Harvest \\
\hline Poppy (P) & $04 / 20$ & $08 / 20$ & $04 / 05$ & $08 / 13$ & $03 / 24$ & $08 / 12$ \\
White clover (C1) & $04 / 24$ & - & $04 / 09$ & - & $03 / 28$ & - \\
White clover (C2) & $05 / 24$ & - & $04 / 24$ & - & $05 / 07$ & - \\
Barley (B1, B2, B3) & $05 / 24$ & $08 / 20$ & $04 / 24$ & $08 / 13$ & $05 / 07$ & $08 / 12$ \\
\hline
\end{tabular}

The aim was an early sowing of poppy, preferably in March, but seedbed preparation is essential for its germination and wet soils in March of 2018 and 2019 prevented such an early sowing in those years. Sowing dates of barley and late white clover were adapted to soil conditions as well, resulting in different seeding dates between years. 
For the purpose of observing weed suppression ability of the intercrops, no mechanical weed regulation or herbicides were applied after sowing of the second crop. In 2019 a single application of a grass herbicide (Fusilade, $1 \mathrm{~L} \mathrm{ha}^{-1}$ ) was executed before crop emergence. This was done because of massive regrowth of previously grown cereals that would not have allowed any poppy growth at that time. In 2018 and 2020 mechanical weeding was done before seeding barley and late white clover (C2). Due to very low weed infestation after crop emergence in 2019, mechanical weeding was not necessary that year. The sites were fenced from seed emergence until harvest to prevent damage from hares.

\subsection{Measurements}

Growth parameters were analyzed depending on poppy developmental stage $(\mathrm{BBCH})$ including leaf area index (LAI), plant biomass, weed coverage, weed number and weed species. The correspondence between BBCH stages and day of year are listed in Table S1. Furthermore, the yield parameters capsule number or ear number, capsule weight, seed number and seed weight as well as straw weight were assessed at harvest. Data was generated for each crop separately on a single row from the center of each plot to reduce boundary effects.

For determining crop phenology, $\mathrm{BBCH}$ growth stages were used, with the extended cereal $\mathrm{BBCH}$ scale for barley and the general extended $\mathrm{BBCH}$ scale for clover [28]. This latter scale was also used for identifying poppy growth stages but slightly modified. Main adaption was the exclusion of stage 2 and 4 due to overlapping with stages 3 and 5 . Accordingly, the following principal growth stages occurred: 10-19,leaf development; 30-39, stem elongation; 50-59, inflorescence development; 60-69, flowering; 70-79, fruit development; 80-89, ripening. The BBCH stages were determined for every plot.

For fresh and dry matter determination, crop samples were collected on each plot from $0.1 \mathrm{~m}^{2}$. An area was chosen in the center of each plot that contained one poppy row and adjacent intercrops when present. The areas were chosen randomly but with distance to plot boarders and previously sampled zones. The plant material was sorted by crop species and its fresh weight was determined. For assessing dry matter, the plant samples were placed in a drying oven at $60{ }^{\circ} \mathrm{C}$ for $48 \mathrm{~h}$ and weighed again. As an intermediate step, before drying, leaves of the crop samples from $0.1 \mathrm{~m}^{2}$ were separated from stems for leaf area measurement. Leaf area was determined by use of a Li-Cor 3100C leaf area meter (Li-Cor, Lincoln, NE, USA). Leaf area index (LAI) was obtained by dividing leaf area $\left(\mathrm{m}^{2}\right)$ by the sampling area. Leaf area was first determined in 2019 and also analyzed in 2020.

For each of the four replicates, the dried material was further processed to analyze nitrogen content in the aboveground biomass. First the dry biomass was shredded with a SM 300 cutting mill (Retsch, Haan, Germany) at $3000 \mathrm{rpm}$ and the use of a $0.25 \mathrm{~mm}$ sieve. For samples that were too small in weight for the SM 300 mill, material was pulverized with a MM 400 ball mill (Retsch, Haan, Germany) at $3000 \mathrm{rpm}$ for $30 \mathrm{~s}$. Then $6 \mathrm{mg}$ of each ground sample were weighed into tin capsules for combustion and gas chromatographic analysis in the EA 3000 Elemental Analyser (HEKAtech, Wegberg, Germany).

Weeds were documented by weed number counting and weed species identification on three evenly distributed areas on each plot, each comprising $0.1 \mathrm{~m}^{2}$, and weed ground coverage as well as crop ground coverage were estimated in percent.

At harvest, poppy and barley plants were collected manually from one row of each plot on three evenly distributed lengths of $1 \mathrm{~m}$, respectively. Moisture content at harvest was $7-9 \%$ for poppy and $12-16 \%$ for barley. Number of plants and capsules or ears were counted. Poppy capsules and barley ears were cut off and counted and the straw was dried for $24 \mathrm{~h}$ at $104{ }^{\circ} \mathrm{C}$ and weighed afterwards. The dry capsules were weighed and cut with a small hack saw to separate seeds from capsules. Seeds of the whole sample were weighed to calculate total seed yield. Barley ears were processed with a Wintersteiger LD 180 laboratory thresher (Wintersteiger, Ried, Austria) and then seeds were weighed. One thousand seed masses of poppy and of barley were determined by weighing 1000 seeds that were counted with a Contador 2 Seed Counter (Pfeuffer, Kitzingen, Germany). 


\subsection{Data Analysis}

For yield comparison the land equivalent ratio (LER) was computed for poppy and barley yields by the formula according to Mead and Willey (1980):

$$
L E R=p L E R a+p L E R b=\frac{Y a}{S a}+\frac{Y b}{S b},
$$

with $Y a=$ Yield of crop a as intercrop, $Y b=$ Yield of crop $\mathrm{b}$ as intercrops, $S a=$ Yield of crop a as sole crop and $S b=$ Yield of crop b as sole crop [29]. The LER defines the relative land area that would be needed by a sole crop to produce the same yield as the intercropping system [29]. An LER > 1 means for a substitutive design that more land would be needed if both crops were sown as sole crops thus indicating a benefit by intercropping. In additive intercropping, LERs between 1 and 2 could be expected due to increased plant density. pLERa and pLERb are partial LERs of each cultivar, describing their individual competitive ability by comparing yields in the intercrop to yields in monoculture.

The trial was analyzed as a one-factorial experiment and overall comparisons were done with a linear model including treatment and year as fixed factors. Due to consistent interactions between year and treatment, analyses of variance (ANOVA) were conducted for the individual years with treatment as a fixed factor for every measured parameter. Normal distribution (Shapiro-Wilk test) and homogeneity of variance (Levene's test) was given for all data except weeds. Tukey HSD tests were chosen for all post-hoc comparisons except for weed data where the Scheffé test was applied. To stabilize estimates for LERs and pLERs, the ratios were calculated with individual plot values for the numerators (intercrops) and averages over all replicates for the denominators (sole crops). Analysis of variance for the LER values was performed with $R$ software (version 1.2.1335) and all other statistical calculations were performed with SPSS 26 software (IBM Ehningen, Germany). Visualizations were made with Microsoft Excel 2019.

\section{Results}

3.1. Yield

\subsubsection{Poppy Yield}

Mean poppy seed yield as sole crop was 831, 1293 and $909 \mathrm{~kg} \mathrm{ha}^{-1}$ in 2018, 2019 and 2020, respectively (Figure 1). The poppy-clover intercrop produced similar yields to poppy sole crop while the combination with barley generated mixed results. Poppy yields from intercropping with both early and late sown clover were similar (no significant differences) to sole-cropped poppy in each year. For poppy-barley intercropping, poppy yields from intercropping were as high as sole crop poppy yields in two of three years (Figure 1). In 2019 poppy yield was significantly lower than sole-cropped poppy in all three poppy-barley combinations, ranging from $155 \mathrm{~kg} \mathrm{ha}^{-1}$ (PB3) to $362 \mathrm{~kg} \mathrm{ha}^{-1}$ (PB1), while poppy sole crop yield was $1293 \mathrm{~kg} \mathrm{ha}^{-1}$. Higher barley seeding densities tended to decrease poppy seed yield even further, but the effect was not as strong as differences between years.

Poppy straw yields responded similarly to seed yields with no differences between $\mathrm{P}$ and PC1 or PC2 (Table 5). Straw yield from poppy-barley intercropping (PB1, PB2, PB3) was significantly lower compared to P, PC1 and PC2 in 2019, which was not the case in 2018 and 2020. One thousand grain weight of poppy did not significantly differ between treatments and ranged from $0.41 \mathrm{~g}(\mathrm{~PB} 3,2019)$ to $0.49 \mathrm{~g}$ (P and PB3, 2020). Similarly, capsule number per plant was not different between treatments but between years. There was more than one capsule per plant on average in 2020 while in others years it was around one capsule per plant. Accordingly, plant number $\mathrm{m}^{-2}$ was higher in 2018 and 2019 compared to 2020. A significant difference in plant density as well as grain number per capsule between treatments was only observed in 2019. Therefore, fewer plants were counted in PB2 and PB3 compared to sole cropped poppy and less than half of the grains per capsule were found in PB3 $(802 \pm 91)$ compared to P ( $2085 \pm 257)$. It must be noted that the values for seed per capsule showed a high variation. 


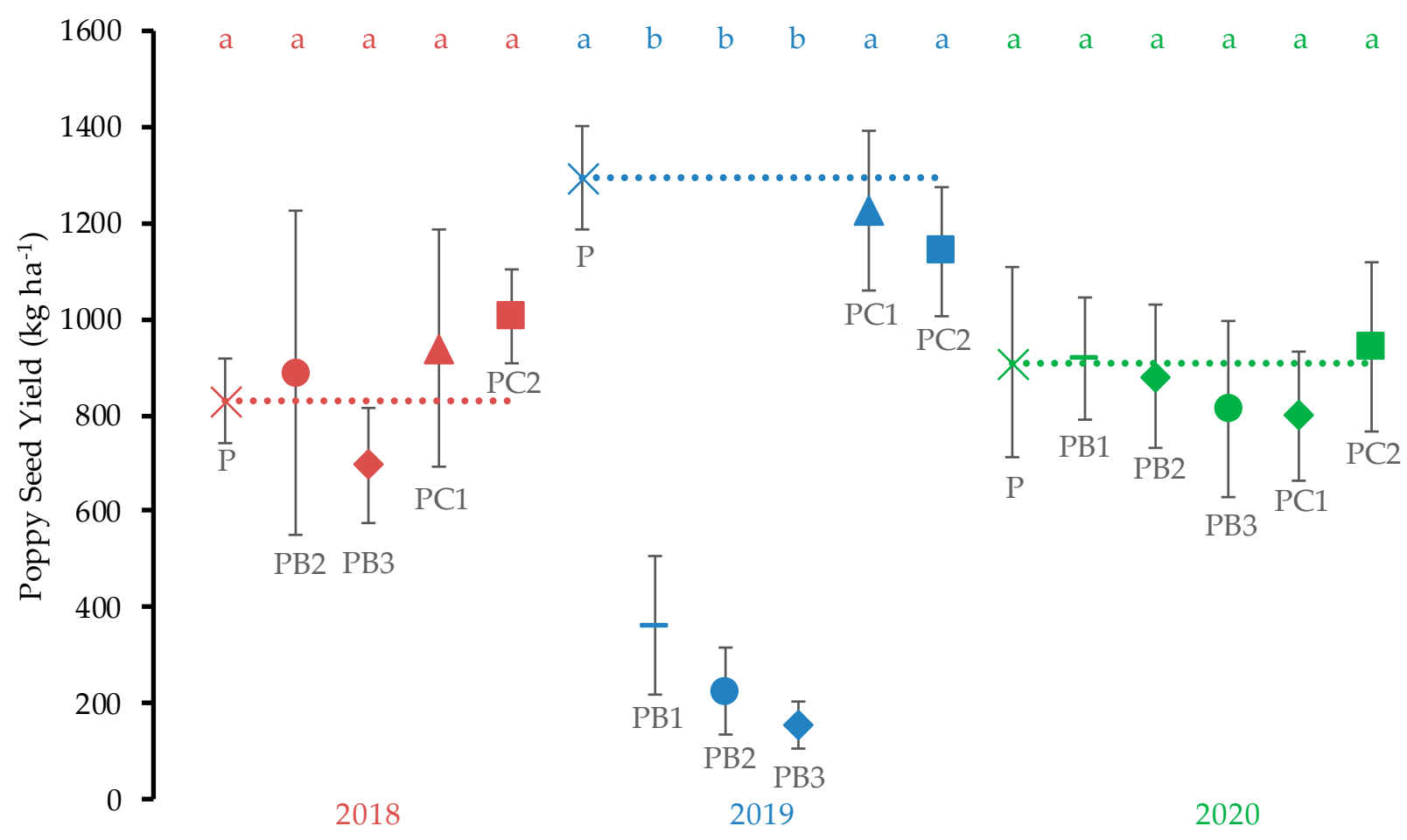

Figure 1. Poppy sole crop seed yield (P) compared to poppy yield intercropped with barley for three sowing densities (PB1 (not in 2018), PB2, PB3) and white clover for two sowing dates (PC1, PC2) in three consecutive years (2018-2020). Means and standard deviations are given for each treatment in each year. Lower case letters indicate significant differences between treatments in each year (ANOVA + Tukey HSD test).

Table 5. Poppy yield data from sole cropping $(\mathrm{P})$ and intercropping with barley for three different sowing densities (PB1 (not in 2018), PB2, PB3) and white clover for two sowing dates (PC1, PC2) at Campus Klein-Altendorf 2018-2020. Lower case letters indicate significant differences between crop treatments for each yield parameter in each year (ANOVA \& Tukey HSD test, $p<0.05)$.

\begin{tabular}{|c|c|c|c|c|c|c|}
\hline Year & Sample & $\begin{array}{l}\text { Straw Yield } \\
\left(\mathrm{kg} \mathrm{ha}^{-1}\right)\end{array}$ & $\begin{array}{c}\text { Thousand } \\
\text { Grain Mass (g) }\end{array}$ & Plants $\mathrm{m}^{-2}$ & $\begin{array}{l}\text { Capsules Per } \\
\text { Plant }\end{array}$ & $\begin{array}{l}\text { Seed Number } \\
\text { Per Capsule }\end{array}$ \\
\hline \multirow[t]{5}{*}{2018} & $\mathrm{P}$ & $2748 \pm 419 a$ & $0.44 \pm 0.03 \mathrm{a}$ & $156.2 \pm 18.1 \mathrm{a}$ & $1.00 \pm 0.05 \mathrm{a}$ & $1245 \pm 287 \mathrm{a}$ \\
\hline & PB2 & $2580 \pm 626 a$ & $0.44 \pm 0.03 \mathrm{a}$ & $118.8 \pm 17.1 \mathrm{a}$ & $1.04 \pm 0.07 \mathrm{a}$ & $1679 \pm 684 a$ \\
\hline & PB3 & $2393 \pm 286 a$ & $0.44 \pm 0.02 \mathrm{a}$ & $128.5 \pm 37.1 \mathrm{a}$ & $0.98 \pm 0.05 \mathrm{a}$ & $1347 \pm 507 a$ \\
\hline & PC1 & $2553 \pm 844 a$ & $0.48 \pm 0.02 \mathrm{a}$ & $107.3 \pm 26.7 \mathrm{a}$ & $1.09 \pm 0.08 \mathrm{a}$ & $1748 \pm 528 \mathrm{a}$ \\
\hline & PC2 & $2823 \pm 191 \mathrm{a}$ & $0.45 \pm 0.01 \mathrm{a}$ & $132.8 \pm 15.6 \mathrm{a}$ & $0.96 \pm 0.15 \mathrm{a}$ & $1779 \pm 353 \mathrm{a}$ \\
\hline \multirow[t]{6}{*}{2019} & $\mathrm{P}$ & $3634 \pm 719 a$ & $0.44 \pm 0.02 \mathrm{a}$ & $158.2 \pm 17.8 \mathrm{a}$ & $0.92 \pm 0.04 \mathrm{a}$ & $2085 \pm 257 \mathrm{ab}$ \\
\hline & PB1 & $1105 \pm 414 b$ & $0.42 \pm 0.02 \mathrm{a}$ & $86.5 \pm 41.4 \mathrm{ab}$ & $0.91 \pm 0.11 \mathrm{a}$ & $1204 \pm 436 \mathrm{~cd}$ \\
\hline & PB2 & $602 \pm 273 b$ & $0.43 \pm 0.01 \mathrm{a}$ & $52.5 \pm 30.3 c$ & $0.97 \pm 0.15 \mathrm{a}$ & $1350 \pm 638 \mathrm{bcd}$ \\
\hline & PB3 & $403 \pm 106 b$ & $0.41 \pm 0.02 \mathrm{a}$ & $52.5 \pm 17.7 \mathrm{c}$ & $0.91 \pm 0.12 \mathrm{a}$ & $802 \pm 91 \mathrm{~d}$ \\
\hline & PC1 & $2880 \pm 388 \mathrm{a}$ & $0.43 \pm 0.03 \mathrm{a}$ & $118.5 \pm 42.9 \mathrm{bc}$ & $0.96 \pm 0.06 \mathrm{a}$ & $2684 \pm 593 a$ \\
\hline & PC2 & $3042 \pm 248 a$ & $0.44 \pm 0.02 \mathrm{a}$ & $149.7 \pm 9.6 \mathrm{a}$ & $0.93 \pm 0.02 \mathrm{a}$ & $1879 \pm 162 \mathrm{abc}$ \\
\hline \multirow[t]{6}{*}{2020} & $\mathrm{P}$ & $2552 \pm 431 \mathrm{a}$ & $0.49 \pm 0.03 \mathrm{a}$ & $65.3 \pm 22.1 \mathrm{a}$ & $1.40 \pm 0.19 \mathrm{a}$ & $4277 \pm 557 a$ \\
\hline & PB1 & $2238 \pm 203 a$ & $0.49 \pm 0.03 a$ & $69.7 \pm 12.7 \mathrm{a}$ & $1.27 \pm 0.12 \mathrm{a}$ & $4344 \pm 865 a$ \\
\hline & PB2 & $2162 \pm 338 a$ & $0.50 \pm 0.01 \mathrm{a}$ & $67.0 \pm 28.0 \mathrm{a}$ & $1.45 \pm 0.51 \mathrm{a}$ & $4141 \pm 477 \mathrm{a}$ \\
\hline & PB3 & $1881 \pm 336 \mathrm{a}$ & $0.49 \pm 0.02 \mathrm{a}$ & $52.3 \pm 10.6 \mathrm{a}$ & $1.51 \pm 0.19 \mathrm{a}$ & $4234 \pm 189 \mathrm{a}$ \\
\hline & PC1 & $1844 \pm 367 a$ & $0.48 \pm 0.03 a$ & $65.5 \pm 26.1 \mathrm{a}$ & $1.42 \pm 0.31 \mathrm{a}$ & $3854 \pm 572 a$ \\
\hline & PC2 & $2631 \pm 397 a$ & $0.48 \pm 0.03 \mathrm{a}$ & $68.3 \pm 15.2 \mathrm{a}$ & $1.35 \pm 0.16 \mathrm{a}$ & $4371 \pm 304 a$ \\
\hline
\end{tabular}




\subsubsection{Barley Yield}

Barley grain yield varied between 981 and $3834 \mathrm{~kg} \mathrm{ha}^{-1}$ (Figure 2). Sole-cropped barley outyielded intercropped treatments significantly in 2018 (B2, B3 compared to PB2, PB3) and 2019 (B2 compared to PB2). The highest yield but also the highest gap between treatments was observed in 2018 when B2 and B3 yielded 3532 and $3826 \mathrm{~kg} \mathrm{ha}^{-1}$ which was significantly more than PB2 and PB3 (1159 and $981 \mathrm{~kg} \mathrm{ha}^{-1}$ ). The difference between sole cropping and intercropping was smaller in 2019 and 2020 (Table S2). Even though barley was the strongest intercrop component in 2019, barley yields were still higher in sole crops (2017-3006 kg ha ${ }^{-1}$ ) than in intercrops (1099-1753 kg ha $\left.{ }^{-1}\right)$. In 2020, both poppy and barley yields were not affected by intercropping. For the intercrop designs no effect of seeding density on barley yield was observed. In sole crops higher seeding densities were associated with higher yields only in 2019 but these differences were not significant. Straw yield was similar to grain yield, producing significant differences between sole crops and intercropped barley in 2018 and 2019 but not in 2020 (Table S2). In contrast, thousand grain weight was similar between treatments in 2018 and 2019 but in 2020 it was significantly higher for B1 (39.66 $\pm 3.03 \mathrm{~g})$ and B2 $(38.64 \pm 1.58)$ compared to PB1 $(30.61 \pm 2.40 \mathrm{~g})$ and PB2 $(31.34 \pm 1.24 \mathrm{~g})$.

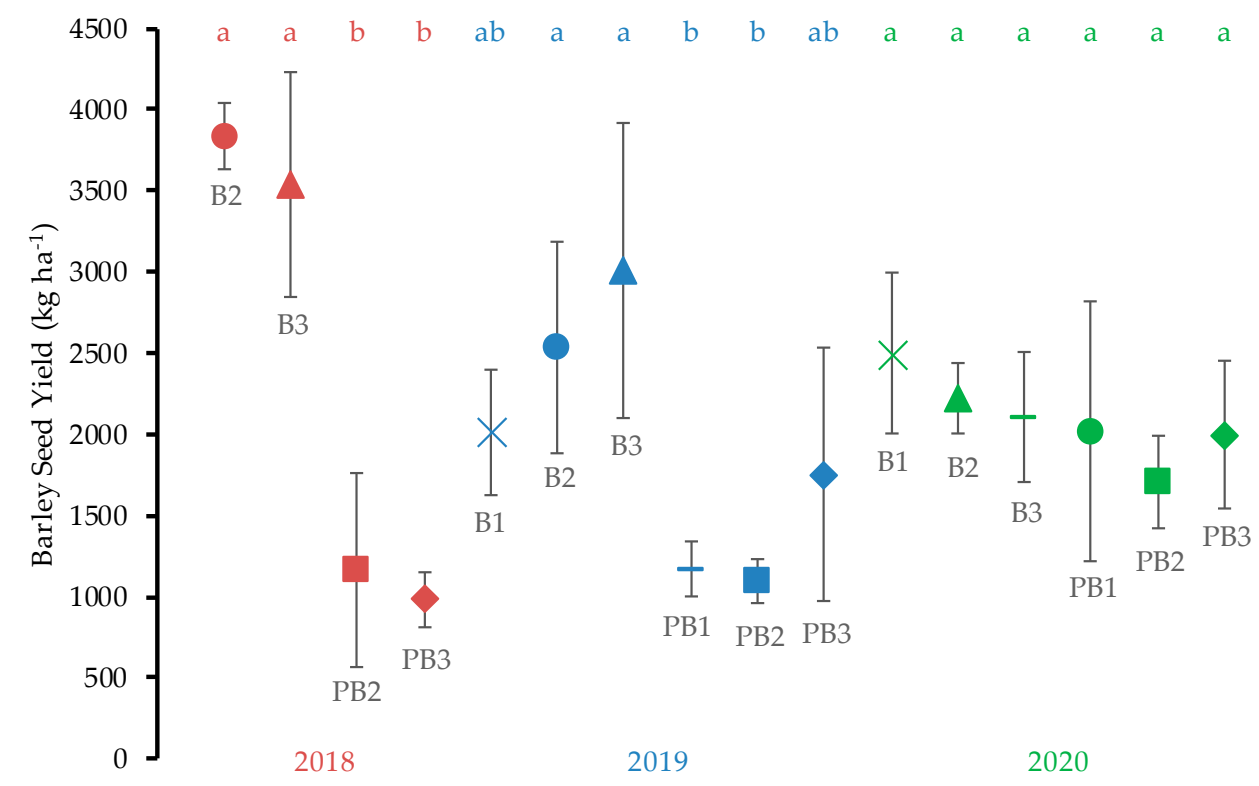

Figure 2. Barley seed yield as sole crop in two (B1, B2; 2018) and three (B1, B2, B3; 2019-2020) different seedings densities compared to barley yields from intercropping with poppy (PB1, PB2, PB3). Lower case letters indicate significant differences between treatments in each year (ANOVA + Tukey HSD test).

\subsubsection{Land Equivalent Ratio (LER)}

The LER of the poppy-barley intercrops was between 1 and 2 for two of the three years (Figure 3). The data are clustered according to years, underlining the dominant year effect, while seeding density did not have a substantial influence on yields and subsequently neither on LERs. The year 2018 marks an exception when the LER of PB3 was higher than the LER of PB2 due to increased poppy yields. Corresponding to significant differences in seed yield between sole-cropped poppy and poppy intercropped with barley, 2019 was the year with the lowest total area productivity in intercropping. pLERs of 2018 and 2020 demonstrated a shift towards higher poppy pLERs of $>0.8$, indicating that in both years poppy contributed essentially to the positive LERs of >1.1 in 2018 (PB2: 1.37; PB3: 1.11) and >1.7 (PB1: 1.82; PB2: 1.73; PB3: 1.84) in 2020. LERs of 2019 were between 0.72 (PB2) and 0.99 (PB3). 


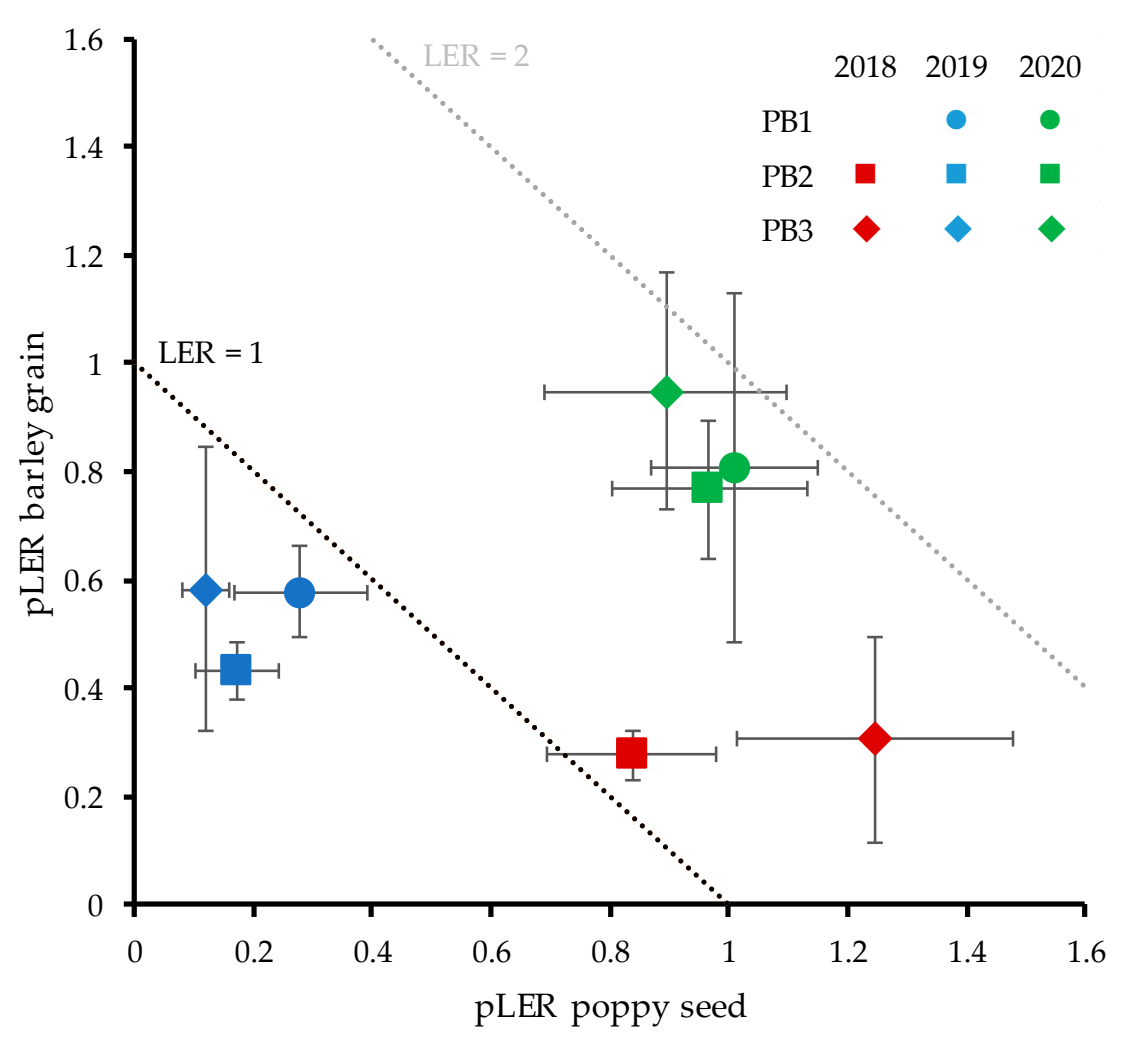

Figure 3. Partial land equivalent ratios (pLER) for poppy and barley yields in the intercropping designs of three different barley seeding densities (PB1 (not in 2018), PB2, PB3) over three years (2018-2020). Symbols and error bars represent means and standard deviations respectively. The dotted lines represent LER $=1$ (black) and LER $=2$ (grey). Analyses of variance showed no significant differences of LER values between seeding densities within each year.

\subsection{Plant Growth}

Competition between poppy and its respective companion crop was observed by measuring plant biomass, leaf area and nitrogen content throughout the growing period.

\subsubsection{Biomass}

Dry matter development of poppy sole crop and intercropped with barley or clover was similar in 2018 and 2020 in contrast to 2019 (Figure 4a). Poppy dry matter increased until capsule ripening and was not negatively affected by intercropping with white clover in all three years. Additionally, sowing date of white clover did not influence poppy dry matter accumulation significantly, although poppy dry matter of PC1 always tended to be the lowest. In 2018 poppy biomass was not significantly different between treatments except for BBCH 85 where poppy biomasses of $\mathrm{P}\left(941.5 \pm 67.8 \mathrm{~g} \mathrm{~m}^{-2}\right)$ and PC2 $\left(1086.9 \pm 17.6 \mathrm{~g} \mathrm{~m}^{-2}\right)$ were significantly higher than those of PB3 $\left(596.7 \pm 121.8 \mathrm{~g} \mathrm{~m}^{-2}\right)$. In 2020 treatment differences were never significant but there was a tendency for poppy sole crop to yield higher biomasses. In 2019, poppy dry matter was reduced in the intercrop with barley. Differences between treatments already occurred from $\mathrm{BBCH} 30$ onward as at that point dry matter of $\mathrm{P}\left(163.8 \pm 23.3 \mathrm{~g} \mathrm{~m}^{-2}\right)$ and PC2 $\left(168.2 \pm 15.7 \mathrm{~g} \mathrm{~m}^{-2}\right)$ were significantly higher than PB3 $\left(94.6 \pm 8.2 \mathrm{~g} \mathrm{~m}^{-2}\right)$. This trend continued up to BBCH 81 when dry matter of P, PC1 and PC2 was between 955.1 and $1260.8 \mathrm{~g} \mathrm{~m}^{-2}$ and significantly higher than dry matter of poppy intercropped with barley $\left(241.5-343.6 \mathrm{~g} \mathrm{~m}^{-2}\right)$. 
(a)

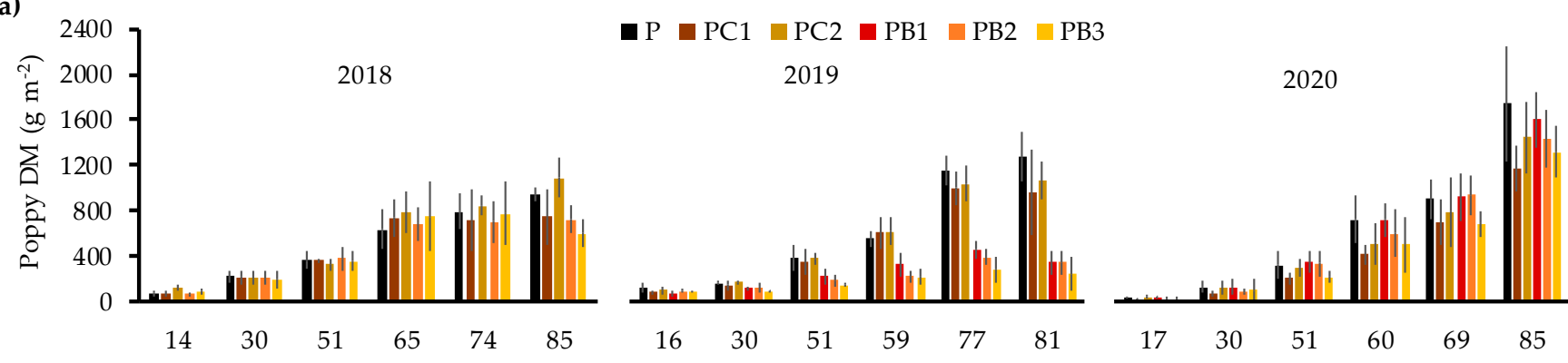

(b)

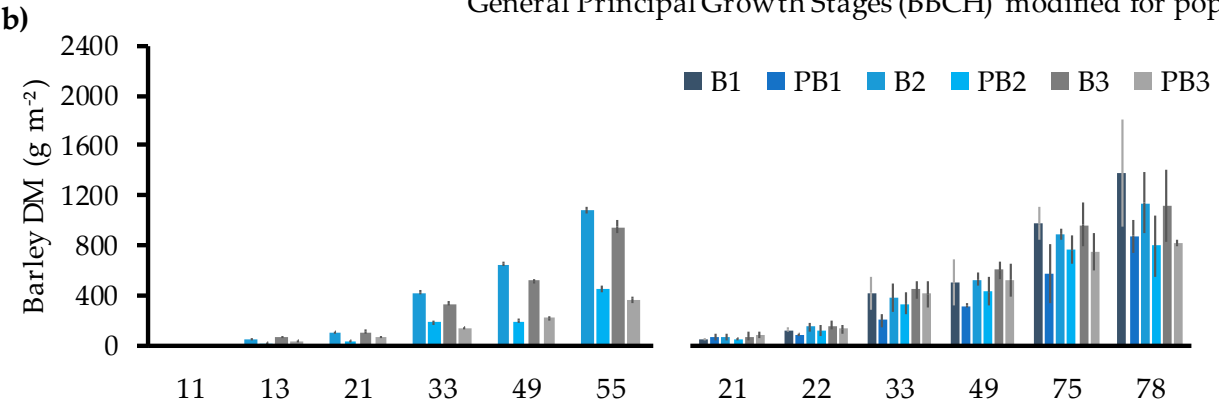

(c)

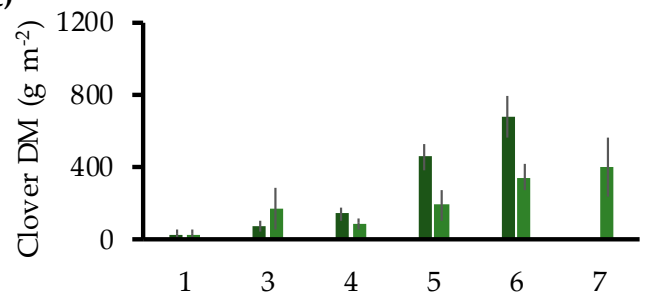

General Principal Grow th Stages (BBCH) of barley

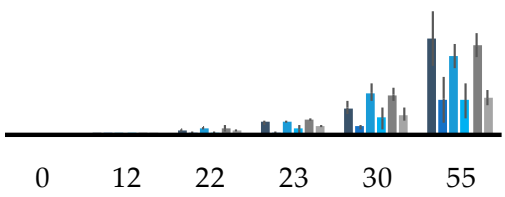

(d)

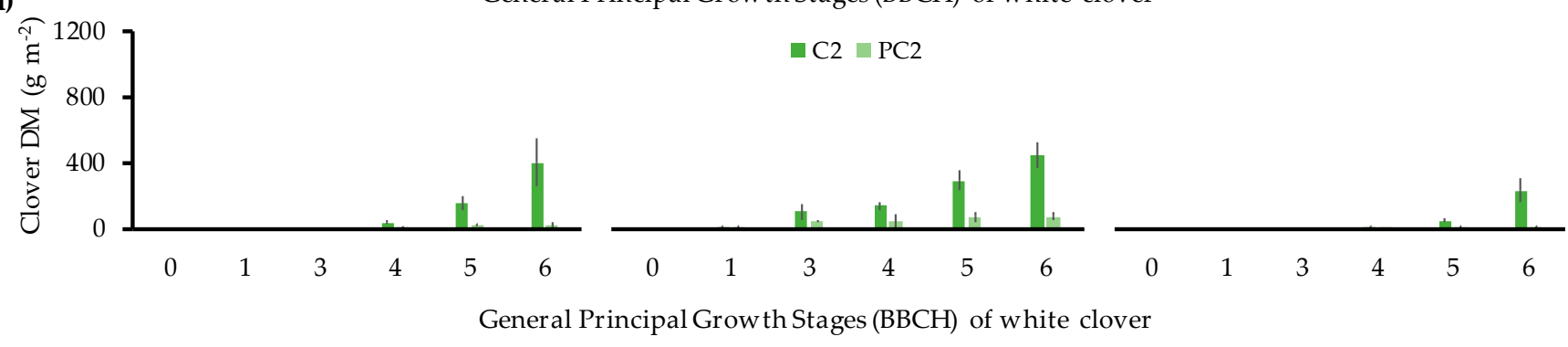

Figure 4. Dry matter $\left(\mathrm{g} \mathrm{m}^{-2}\right.$ ) of (a) poppy, (b) barley, (c) early sown clover and (d) late sown clover as sole crops (P, B1, B2, B3, C1, C2), in poppy-barley intercropping (PB1, PB2, PB3) and poppy-white clover intercropping (PC1, PC2). Detailed descriptive and inferential statistics can be found in Tables S3-S5.

Barley dry matter development was opposed to the pattern of poppy as its biomass accumulation in 2019 was stronger compared to 2018 and 2020. The biomass data revealed that when there was strong competition with barley, it started early, at the beginning of poppy elongation growth. In 2019, barley was already at the developmental stage BBCH 21 while poppy was at $\mathrm{BBCH} 16$, resulting in earlier biomass build-up than in the other years when barley was not present in noteworthy amounts at that time. Therefore, overall biomass accumulation of barley was high in 2019 with amounts ranging from $790.2 \pm 248.7$ (PB2) to $1373.2 \pm 427.5 \mathrm{~g} \mathrm{~m}^{-2}$ (B1) at its ripening (BBCH 78). In each year there was a tendency of sole cropped barley to gain more dry matter than the respective intercrops, which is consistent with barley yield data of 2018 and 2019 where significantly higher yields were achieved in sole cropped barley. The influence of barley seeding density on barley dry matter was smaller than the influence of the intercrop and the individual years. 
The later sown clover did not achieve as much biomass as the early sown treatments, especially in 2018 and 2020 (Figure 4b). Additionally, clover dry matter in intercropping was mostly smaller than in sole cropped clover. In 2018 and 2020, differences between sole cropping and intercropping were statistically significant from BBCH 5 (C1) onward. Further differences were evident at the same time for the late sown clover that accumulated more dry matter in sole cropping compared to intercropping (C2: $149.7 \pm 42.6 \mathrm{~g} \mathrm{~m}^{-2}$; PC2: $19.2 \pm 4.2 \mathrm{~g} \mathrm{~m}^{-2}$ ). Dry matter of PC2 was almost irrelevant in 2018 and 2020 with a final level of $17.7 \pm 14.2$ and $7.8 \pm 8.6 \mathrm{~g} \mathrm{~m}^{-2}$. Contrarily, in 2019 the later sown clover grew biomass in amounts up to $71.7 \pm 24.0$ (PC2) and $441.1 \pm 76.8 \mathrm{~g} \mathrm{~m}^{-2}$ (C2) at BBCH 6 (C2). Thus, late clover sowing as an intercrop with poppy was unsuccessful in two of three years. Dry matter accumulation of early sown clover was mostly higher as sole crop than in intercrop, revealing that under the given trial conditions clover had a lower competitive ability than poppy when brought into competition.

\subsubsection{Leaf Area}

Leaf area of poppy was analyzed in 2019 and 2020 (Table 6) and reached maximum in both years at flowering stage. LAI was higher in 2020 reaching $7.4 \pm 2.7$ (BBCH 60) for sole cropped poppy while in 2019 it was $4.9 \pm 0.8$ (BBCH 59). Maximum LAI at flowering was followed by a decrease that was stronger in 2019 where LAIs dropped below 3.0. During capsule ripening, leaves start to turn brown and fall off and this phenomenon occurred earlier in 2019 than 2020, explaining the greater LAI decrease at BBCH 77. Differences between treatments in 2019 are consistent with biomass development. In 2019, LAI of poppy intercropped with barley was consistently lower than that of sole cropped poppy and poppy-clover intercropping. This separation began early in development, resulting in significantly higher LAIs of 4.8-5.1 for P, PC1 and PC2 compared to 1.4-2.5 for PB1, PB2 and PB3 at BBCH 59. In both years, there was a tendency of poppy LAI decreasing with increasing barley seed density.

Table 6. Leaf area indices of poppy as sole crop (P) and intercropped with clover (PC1, PC2) and barley (PB1, PB2, PB3) at different BBCH growth stages at Campus Klein-Altendorf 2019 and 2020. Lower case letters indicate significant differences between crop treatments for each growth stage in each year (ANOVA \& Tukey HSD test, $p<0.05$ ).

\begin{tabular}{|c|c|c|c|c|c|}
\hline \multirow[b]{2}{*}{ Year } & \multirow[b]{2}{*}{ Sample } & \multicolumn{4}{|c|}{ LAI at Poppy Principal Growth Stages (BBCH) } \\
\hline & & ВВСН 30 & ВВСН 51 & ВBCH 59 & ВВСН 77 \\
\hline \multirow{6}{*}{2019} & $\mathrm{P}$ & $3.99 \pm 0.75 \mathrm{a}$ & $4.46 \pm 1.35 \mathrm{a}$ & $4.88 \pm 0.84 \mathrm{a}$ & $2.54 \pm 0.62 \mathrm{a}$ \\
\hline & PC1 & $3.02 \pm 0.79 \mathrm{abc}$ & $3.84 \pm 1.16 \mathrm{ab}$ & $4.83 \pm 0.78 \mathrm{a}$ & $2.23 \pm 0.65 \mathrm{a}$ \\
\hline & PC2 & $3.11 \pm 0.44 \mathrm{ab}$ & $4.22 \pm 0.53 \mathrm{ab}$ & $5.12 \pm 0.83 \mathrm{a}$ & $2.31 \pm 0.59 \mathrm{a}$ \\
\hline & PB1 & $1.54 \pm 0.42 \mathrm{~d}$ & $2.26 \pm 0.58 \mathrm{bc}$ & $2.52 \pm 1.16 \mathrm{~b}$ & $0.70 \pm 0.27 \mathrm{~b}$ \\
\hline & PB2 & $1.64 \pm 0.93 \mathrm{~cd}$ & $1.74 \pm 0.46 c$ & $1.69 \pm 0.41 b$ & $0.59 \pm 0.26 b$ \\
\hline & PB3 & $1.77 \pm 0.46 \mathrm{bcd}$ & $1.39 \pm 0.14 \mathrm{c}$ & $1.44 \pm 0.27 \mathrm{~b}$ & $0.51 \pm 0.50 \mathrm{~b}$ \\
\hline Year & Sample & ВВСН 30 & ВВСН 51 & ВВСН 60 & ВВСН 69 \\
\hline \multirow{6}{*}{2020} & $\mathrm{P}$ & $2.11 \pm 0.82 \mathrm{a}$ & $4.41 \pm 1.92 \mathrm{a}$ & $7.36 \pm 2.69 \mathrm{a}$ & $6.35 \pm 1.56 \mathrm{a}$ \\
\hline & PC1 & $1.04 \pm 0.51 \mathrm{a}$ & $2.47 \pm 0.78 \mathrm{a}$ & $3.19 \pm 0.99 \mathrm{a}$ & $4.47 \pm 1.35 \mathrm{a}$ \\
\hline & PC2 & $1.84 \pm 0.84 \mathrm{a}$ & $4.04 \pm 1.32 \mathrm{a}$ & $4.87 \pm 1.53 \mathrm{a}$ & $6.21 \pm 3.16 \mathrm{a}$ \\
\hline & PB1 & $1.97 \pm 1.25 \mathrm{a}$ & $4.60 \pm 1.55 \mathrm{a}$ & $6.68 \pm 1.63 \mathrm{a}$ & $6.70 \pm 1.56 \mathrm{a}$ \\
\hline & PB2 & $1.53 \pm 0.51 \mathrm{a}$ & $4.27 \pm 1.61 \mathrm{a}$ & $5.30 \pm 2.04 \mathrm{a}$ & $6.10 \pm 1.21 \mathrm{a}$ \\
\hline & PB3 & $1.59 \pm 1.49 \mathrm{a}$ & $2.57 \pm 0.87 \mathrm{a}$ & $4.39 \pm 2.86 a$ & $4.25 \pm 1.16 \mathrm{a}$ \\
\hline
\end{tabular}

Treatment differences were not as pronounced in 2020 as in 2019. LAI of PC1 was always the lowest $(3.2 \pm 1.0$ at $\mathrm{BBCH} 60)$ while the others were $>4.0$. This tendency of PC1 ranking lowest was also found in biomass and seed yield of poppy and gives a hint that early clover can still have a competitive influence on poppy growth. Barley and clover LAI were measured in the same as poppy and are available in the Supplementary Materials (Tables S6 and S7). 


\subsubsection{Nitrogen}

The pattern of nitrogen content in the poppy plants was similar in each year as there was a continuous decrease in nitrogen throughout the growing period (Figure 5). However, the initial $\mathrm{N}$ amounts differed between years and treatments. Poppy intercropped with clover tended to have higher nitrogen levels than poppy intercropped with barley.

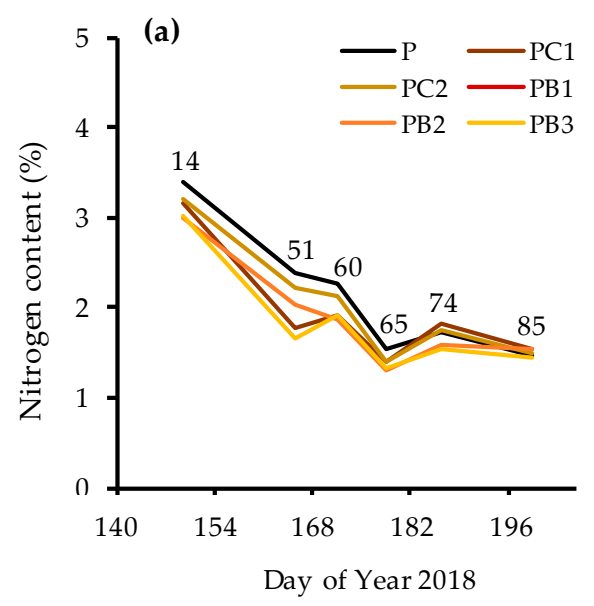

(b)

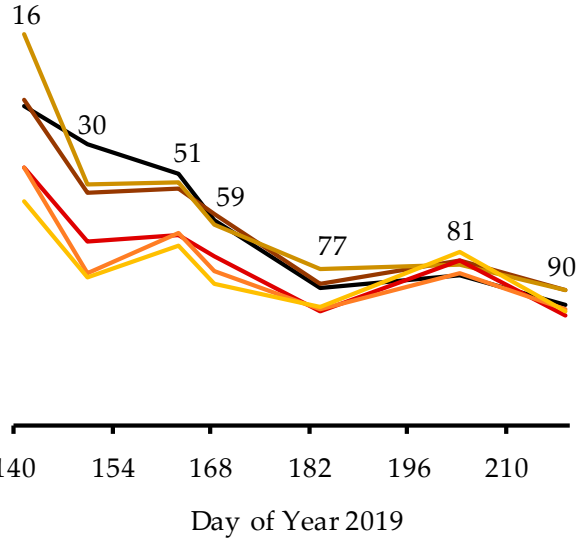

(c)

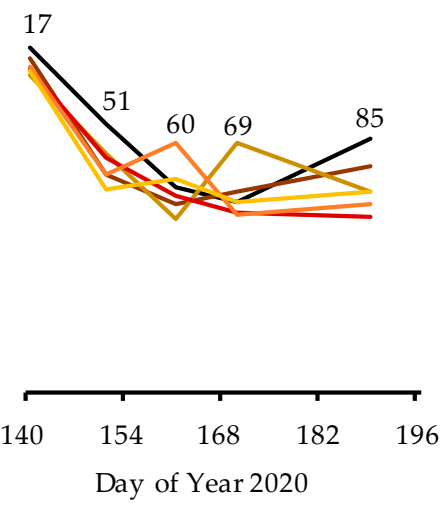

Figure 5. Nitrogen content of poppy plants from sole cropping $(\mathrm{P})$, intercropped with barley at three different seeding densities (PB1, PB2, PB3) and intercropped with white clover at two different sowing times (PC1, PC2) in (a) 2018, (b) 2019 and (c) 2020. General principal growth stages $(\mathrm{BBCH})$ as adapted for poppy are given in twodigit numbers at each sampling point. Detailed descriptive and inferential statistics can be found in Tables S8-S10.

In 2018 and 2020 the amount of nitrogen present at poppy BBCH 14/17 was between $3.00 \%$ and $3.84 \%$, without significant differences between treatments in each year. In 2018, PB2 and PB3 continued to be under the lowest ranking treatments concerning $\mathrm{N}$ levels but this was only significant for BBCH 51 when sole cropped poppy had significantly more nitrogen $(2.38 \% \pm 0.15 \%)$ than poppy from PB3 $(1.66 \% \pm 0.14 \%)$. In 2019 a higher initial discrepancy between nitrogen contents was observed as PC2 and started with significantly higher nitrogen amounts $(4.37 \pm 0.48 \%)$ than PB3 $(2.49 \pm 1.00 \%)$. There was also a grouping of $\mathrm{P}, \mathrm{PC} 1$ and PC2 scoring constantly higher than the barley intercropped treatments (PB1, PB2, PB3) in 2019 but the differences between both groups declined during development. Nevertheless the trend was similar to 2018, where competition for nitrogen was stronger in poppy-barley intercropping as opposed to intercropping with clover as both PC1 and PC2 did not differ significantly in nitrogen content compared to poppy sole cropping. In 2020 there was almost no different nitrogen content between treatments except for BBCH 69 when PC2 showed higher N content (2.79\% $\pm 0.57 \%)$ than PB1 and PB2 (1.97-2.00\%). As the decline in nitrogen was weaker compared to other years, leaving above $1.95 \% \mathrm{~N}$ before harvest, competitive effects for nitrogen did not occur to a significantly measurable extent.

\subsubsection{Weeds}

Weed data was prone to high variations due to an irregular distribution of weeds in the field. C. album was the species found most often throughout years and treatments, followed by Cirsium arvense L., Matricaria sp. and Solanum nigrum L. Total ground cover (without weeds) at harvest of the sole cropped poppy plots was the lowest of all treatments, ranging from $55.9 \pm 4.3 \%$ in 2018 to $68.3 \pm 17.8 \%$ in 2020 . Only the ground cover of PC2 in $2018(54.8 \%)$ was similarly low due to minor growth of the late sown clover. The desired effect of an increased ground cover through intercropping was, however, fulfilled by PC1 (85-100\%), PB1 (97-98\%), PB2 (83-100\%) and PB3 (89-98\%). The combination of poppy with all barley seeding densities or with early clover resulted in total crop ground cover rates of $\geq 90 \%$ in 2019 and 2020 and $>80 \%$ in 2018 . 
Weed infestation was generally low and a weed suppressing effect of the intercrops was not statistically significant compared to sole cropped poppy due to large standard deviations. Variation was especially high in the sole cropped poppy with a weed coverage of $1.3-20.0 \%$ in $2018,4.5-43.4 \%$ in 2019 and $0-20.0 \%$ in 2020 . There was a tendency of poppy-barley intercropping to suppress weeds more successfully as there was below $4 \%$ of weeds on average in any of the barley-poppy intercrops and even below 2\% in 2018 and 2019. White clover as a sole crop did not suppress weeds substantially, in particular when sown late. The highest weed infestation was noticed for the sole-cropped C2 treatments ( $28.4 \pm 18.6 \%$ in 2018 and $45.8 \pm 30.2 \%$ in 2020$)$ which was significantly more than in the other treatments in every year, presumably due to the weak growth of the late sown clover. In intercropping, however, PC1 and PC2 (except for PC2 in 2020) produced only a weed cover of $\leq 5 \%$.

Weed number and weed biomass were determined in 2019 and 2020 but agreed with the weed coverage results. There was a tendency for elevated weed numbers in the plots of P, C1 and C2 in 2019 whereas this tendency was less marked in 2020. At 2019 harvest, sole cropped poppy plots contained 3.3-53.3 weeds $\mathrm{m}^{-2}, \mathrm{C} 1$ had $6.6-30.0$ and $\mathrm{C} 2$ had 13.3-26.7 weeds $\mathrm{m}^{-2}$ compared to zero weeds in PB1, PB3 and B3 and $<5$ weeds $\mathrm{m}^{-2}$ in the other treatments. Similarly, in 2020 weed numbers were $0-10$ in P and 3.3-10 weeds $\mathrm{m}^{-2}$ in C2 in contrast to zero weeds in PB2 and $<5$ weeds $\mathrm{m}^{-2}$ in the other treatments. Weed biomass was characterized by a similarly high variation that was particularly large for the sole cropped poppy and clover treatments (Table S11).

\section{Discussion}

\subsection{Yield Effects}

Poppy seed yield and growth parameters (biomass, LAI, nitrogen content) revealed that 2019 was different from 2018 and 2020, indicating a dominant year effect on intercrop performance. Poppy seed yields as sole crops highly fluctuated but were always above the 10 year European average of $756 \mathrm{~kg} \mathrm{ha}^{-1}$ (2008-2018) [30] so that 2019 can be considered a high-yielding poppy year at the experimental site.

Ground covering intercrops, like white clover, can reduce yields of the main crop in case of high competition for water or nutrients, particularly nitrogen [3]. However, poppy yields and poppy biomass were not affected by intercropping with white clover, implying that competition for those resources between poppy and clover was small. Similarly, Gerhards et al. (2018) showed that clover did not reduce grain yields of spring cereals [31]. Because seeding date of clover also did not affect poppy development, it implicates flexibility in choosing seeding dates of clover as a ground covering intercrop. A yield advantage of an intercrop can occur when the crops do not compete for the same ecological niches and interspecific is weaker than intraspecific competition [1]. In this case the differences in the ecological niches of poppy and clover allowed poppy to achieve its yield potential, not increasing total poppy yield but keeping it on a high level. Additionally, the multiple benefits of intercropping, like erosion control and soil fertility conservation through increased ground cover or nitrogen fixation by a legume, can be exploited without interfering with the poppy harvest [5,7].

In combination with barley, yields were comparable to the sole cropped poppy yield in 2018 and 2020 but were significantly reduced in 2019. This year effect can mainly be attributed to weather conditions and seeding dates as barley was sown earlier in 2019 compared to the other years, which strongly promoted barley growth and thus competitive strength against poppy. For stabilizing poppy, a difference of $4-6$ weeks between poppy and barley sowing was favorable for poppy and this worked best when poppy was sown already in March (2020). Secondly, spring and summer of 2018 and 2020 were predominantly dry and hot (Table 1) while water supply in 2019 was higher (Table 1). As barley is particularly sensitive to water deficits and heat [32,33], this explains its weakness in those years. As a result, poppy was the stronger intercrop component compared to barley in two of the 
three years, as its yields were not depressed by intercropping. Therefore, the success of poppy-barley intercropping depends on how water supply and seeding dates coincide.

The environment plays a fundamental role in plant-to-plant interactions, e.g., competition and facilitation processes depend on the severity of the growing conditions [34], meaning that plants react differently towards each other under limited resource availability. This could be an explanation of why competition coming from barley was lower when water was a limiting growth factor. However, poppy grew despite limited precipitation in 2018 and 2020, indicating that it is able to cope with adverse environmental conditions, which could be an advantage facing future growing conditions due to climate change. These results must be considered with regard to the soil conditions as the trials were conducted on a highly fertile luvisol that compensates water and nutrient deficits to some degree [35].

Delayed sowing of barley produced grain yields that were lower than average spring barley yields in Germany that were $5330 \mathrm{~kg} \mathrm{ha}^{-1}$ for the timeframe of 2014-2019 [36]. This was not unexpected as the sowing date for spring barley in our experiment was much later than is normally the case in Germany. As poppy was the main crop in the intercropping system, delayed sowing was chosen on purpose to give poppy a head start, implicating limitations for the yield potential of barley. Due to individual climate and soil conditions in each year, it was impossible to implement identical seeding dates every year but this revealed that seeding date and climatic conditions had the strongest effect on the intercropping systems, underlining the significant role of the environment involved in the performance of intercrops [7,37]. Differences between seeding densities were particularly small for the intercrop designs. Vandermeer (2012) stated that intraspecific competition is often higher than interspecific competition, [4] meaning that high barley seeding densities can be unfavorable for barley itself. Higher plant densities can provide yield advantages, but limited resources will be exhausted earlier [7]; thus, only under favorable water supply in 2019 did higher barley seeding densities result in higher seed yields. However, barley was affected by intercropping in 2018 and 2019, when yields were higher as sole crops compared to intercrops. Contrarily, in 2020 both poppy and barley yields were not affected by intercropping. It was observed that under unfavorable growing conditions the differences between a dominant and a suppressed crop tend to be less intense [7]. Both seeding dates of poppy and barley were realized early in 2020 but the dry growing conditions probably prevented both crops to realize their yield potential and competitive abilities.

Plant densities of poppy after emergence were similar in 2018 and 2019 but lower in 2020 as a result of less favorable germination conditions in 2020 (dry soil). This is why plant density at harvest was also lower in 2020 than in the other years. It is known that fewer plants $\mathrm{m}^{-2}$ usually build more capsules per plant, not necessarily leading to any total seed yield differences [22], as indicated by the higher seed number per capsules. This explains the higher capsule number per plant in 2020 but might also be a reason for less competition in intercropping in 2020, as it reduced the total plant density in each treatment as well. Resulting from the yield differences between years, a LER > 1 was achieved in 2018 and 2020. Due to the additive design, a maximum LER of 2 could be expected if there was no interaction between both components. However, the increased plant density in intercropping induces competition that will lower both individual yields to some extent. With that in mind, the LERs of 2020 (>1.7) reveal that this competition was relatively minor. Partial LERs for barley were higher in 2020 than in 2018 which is why the highest LERs in total were also calculated for 2020. To assess the success of an intercrop, the LER is an insufficient criterion, as for instance the economic value of both crops differs substantially, with poppy usually being the higher priced crop. Nonetheless, the LER results support the conclusion from yield data that moderate yields of both crops increase overall productivity of the intercrop by limiting competition. 


\subsection{Effects on Biomass, Leaf Area and Nitrogen Content}

Biomass and leaf area of poppy and barley also reflected the competition between both crops that was stronger in 2019 compared to 2018 and 2020. In a study with spring barley in Lithuania, highest biomass increase was reported at barley heading that was associated with rainfall events [33]. That might be one reason why overall biomass accumulation of barley was particularly high in 2019. In intercropping with rape and pea, barley dominated the intercrop, accounting for the largest part of biomass [37]. Thus, if not manipulated by late sowing, barley would probably have dominated poppy biomass as well, which emphasizes the importance of supporting poppy by earlier sowing. Due to rapid growth of barley, its competitive abilities can influence the companion crop early on [37] which accordingly happened most intensively in 2019, leading to fewer poppy plants of low biomass in poppy-barley intercropping.

In this trial, dry matter accumulation of early sown clover was more reduced in the intercrop than as sole crop, giving a hint that it was inferior to poppy when brought into competition. Clover biomass data further implies that sowing dates in late April or early May are too late for a ground covering biomass growth. When white clover was sown between spring cereals simultaneously and again under sown approximately 30 days later, dry biomass of the late sown clover was only $2-3 \mathrm{~g} \mathrm{~m}^{-2}$ at DAS 95 compared to $8 \mathrm{~g} \mathrm{~m}^{-2}$ in the early sowing [31]. The same tendency of reduced clover dry matter when sown later than the companion crop was observed in this study. Therefore, early sowing of both crops ensures sufficient clover biomass buildup in intercropping.

In an experiment by Yadav et al. (1984), poppy plants reached a maximum average LAI of 4.02-5.13 [38], similar to our findings in 2019. Willey et al. (1990) reported differences in light use of an erect (millet) and a low crop (groundnut). Light use was not increased in total, but the intercrop still produced a larger LAI, meaning that the same amount of light was distributed more efficiently between both crops as the erect crop used higher and the low crop used lower light intensities [9]. In our case, poppy and barley are both erect crops while clover is low to the ground, probably facilitating light use in the poppy-clover intercrops. Poppy leaf area was less affected by the clover than by the barley intercrop and early clover and high barley seeding densities tended to decrease poppy LAI. Therefore, maximizing poppy LAI is only possible without an intercrop or with late sown clover. Intercropping with crops of similar light use, like barley, reduces poppy leaf area but a lower LAI might still be acceptable if yields are unaffected or compensated by increased total yields of the intercrop.

A decreasing nitrogen content in poppy plants thoughout the growing period is commonly reported. For instance, poppy leaf $\mathrm{N}$ contents decreased to $54 \%$ of their initial content at seed maturity [39], partly due to higher nitrogen accumulation in the seeds [39,40]. Nitrogen concentrations of (alkaloid) poppy plants were reported to be in the range of $4.76-4.93 \%$ at leaf rosette stage, decreasing to $1.83-2.47 \%$ at flowering stage, depending on $\mathrm{N}$ fertilization [41]. In the present study the nitrogen decrease towards the end of the growing period was smaller and levels were finally similar for each treatment. However, there were differences in nitrogen content between sole cropped poppy and poppy intercropped with barley at the beginning of the growing period 2019. This does not automatically mean higher competition for nitrogen but indicates the weakness of the poppy plants in poppy-barley intercropping compared to the other treatments at early development stages.

Clover is able to use atmospheric nitrogen through its root nodule bacteria, making it less dependent on soil nitrogen supply [27] and thus, a weaker competitor for soil $\mathrm{N}$ than barley. Additionally, less demand for nitrogen could also be attributed to the lower amounts of clover biomass compared to barley. According to Liebmann (1986), the combination of mustard and barley resulted in lower leaf $\mathrm{N}$ concentration in mustard but no effect on mustard $\mathrm{N}$ was observed for mustard and pea in intercropping [42]. Likewise, in poppy and barley intercropping, the nitrogen content in poppy was partly affected while it was not affected by the legume (clover). Poppy might not directly benefit from the nitrogen accumulation through clover as the $\mathrm{N}$ transfer is probably higher to the following crop [9], 
but competition for soil nitrogen might be smaller. Therefore, the use of a legume like clover could be a benefit for poppy nitrogen supply but could also contribute to more weed growth as soil nitrogen is less depleted by the intercrops [19].

\subsection{Weed Suppression}

The weed regulation effectiveness of intercropping varies dependent on many factors such as choice of crop species, seeding dates and densities, preceding crop, soil and weather conditions, weed seed bank or site management factors [3,8]. In many intercropping systems, weed suppression is only a function of increased total crop density [3,17] which was higher in our intercrops as well compared to the sole cropped plots.

However, barley had a weed suppressing effect itself, as weed infestation in the sole cropped barley treatments was only once above $1 \%$. The most weed suppressive intercrops include crops with a rapid, early growth and a dense canopy [3]. All three factors apply to barley. Achieving high weed suppression without yield reduction of the main crop is a difficult task [27] and the main crop yields may be at risk as shown in the poppy seed yield in 2019. In correspondence to yield, biomass, leaf area and $\mathrm{C} / \mathrm{N}$ data, high seeding densities of barley may increase competition with poppy, but they also intensify competition with weeds resulting in nearly weed-free intercrops of poppy with barley.

White clover was said to provide the best compromise between weed suppression and yield reduction of the main crop when compared to other under sown clover species [27]. However, C. album was almost unaffected by each of the clover species. This may explain why weed suppression of white clover in our experiment was weak. Despite its weak weed suppressing effect as the sole crop, clover as an intercrop with poppy can still add to the competition against weeds when intercropped with poppy, in particular when providing enough biomass as in the early sown clover. Szumigalski and van Acker (2005) determined a dominant effect of environmental conditions on weed density and weed biomass in annual intercrops that was much greater than the crop treatment effect [8]. Accordingly, differing climatic conditions and inhomogeneous weed distribution led to high variation in weed coverage, weed number and weed biomass, particularly in sole cropped poppy. Mechanical weeding before sowing of late clover and barley was necessary in 2018 and 2020 but weed infestation was very low in 2019 at the start of the trial and the different treatment could also have influenced weed development. However, this also confirms it is important to adapt cultivation strategies to local conditions and that a combination of first mechanical weeding and then intercropping can be helpful to provide sufficient weed suppression throughout the growing period.

\subsection{Poppy Intercropping Perspectives}

Environmental conditions (e.g., soil and weather) and management (e.g., sowing dates, crop protection) are key factors in deciding on an intercropping design for poppy. Additive intercropping can be productive in high-yielding environments [7], which was shown by high LERs for poppy-barley in two of the three years at the trial site. However, adjusting seeding dates was necessary to balance competitive effects of both crops and were still influenced by water and nitrogen as the main growth limiting resources. Therefore, low growing, less competitive crops like clover are the optimal choice to ensure poppy yields, especially when resources are limited. As competition is low, they can be implemented in the intercropping system as early as possible. An increase in area productivity can be achieved by integrating harvestable crops like barley into the system but it requires site specific management and increases the risk of yield losses. For limited competitive effects, reduction in seeding densities of both crops might be considered to keep total plant density on the same level as in a sole crop (substitutive intercropping).

In general, a balance must be achieved between higher weed suppression by more competitive partners and possible yield losses of the main crop. Replacing mechanical weed regulation by intercrops saves time and money, but also lacks it soil aeration effect. For risk minimization, an earlier sowing date of poppy (4-5 weeks) and lower seeding 
densities of competitive companion crops like barley are recommendable to increase the competitive abilities of poppy. Therefore, the specific interactions of the intercropped crops and their mechanisms in suppressing weeds should be the focus of future intercropping research to determine when and how manipulations in seeding dates, seeding densities or fertilization are necessary. Instead of barley, other cereals could be an alternative, e.g., oats can have a weed reducing effect as well $[14,43]$. Further, intercropping poppy with grain legumes such as lupins, peas or beans, could implement both the advantage of reduced competition for nitrogen as well as a second harvestable crop of economic value.

The advantages of intercropping, like increasing area productivity, biodiversity and soil fertility, can also be incorporated by poppy intercropping systems. Establishing more diverse agroecosystems is a central goal of the European Agricultural Policy including monetary rewards for some types of intercropping. In this context, incorporating nitrogen fixating plants in a poppy intercrop may become particularly attractive for farmers.

In the face of climate change and an increase in unpredictable growing conditions, intercropping distributes risks on more than one crop and is therefore a promising strategy for poppy cultivation. However, further research needs to elucidate if results on poppy intercropping are indeed transferrable to less favorable soil conditions by testing these systems under more diverse environments.

\section{Conclusions}

Poppy intercropped with clover was not severely impacted by competition as indicated by similar poppy yield, biomass, LAI and nitrogen content compared to poppy sole crops. This was mainly attributed to limited competition for water, light and soil nitrogen and a smaller demand of clover for exploiting these resources due to less biomass growth and its nitrogen fixation abilities. Seeding dates of clover did not have a major impact on yield and plant morphology but an earlier sowing date secured sufficient biomass build up to exploit the benefits of an increased ground cover. Therefore, implementing low growing intercrops like white clover into a poppy intercrop should be realized simultaneously to the poppy. Barley and poppy intercrops produced acceptable poppy yields compared to sole crops in two of three years. Early seeding dates and increased water supply enhanced the competitive abilities of barley, lowering poppy yields, LER, LAI, biomass and nitrogen content in intercropping with barley. Competition for nitrogen was strong particularly in the early phases of development. Higher seeding densities of barley tended to increase competitive effects, but the influence of climatic and management factors was stronger. Therefore, when choosing tall growing, biomass rich crops like barley, the poppy crop must be supported by earlier sowing or lower seeding densities of the second crop to ensure competitive equality in the intercrop. The effect of intercropping on weeds was small due to high variability in weed distribution and years with overall low weed infestation. However, a tendency towards lower weed ground cover in intercropping treatments was observed, in particular with barley. Higher plant densities in intercropping may be responsible for why poppy-clover intercrops were also less weedy than both sole crops.

In summary, intercropping poppy with barley requires precise management and earlier sowing of the poppy crop to limit the competitive abilities of barley. Clover appears to be a promising intercrop for poppy as it added ecological benefits while not affecting poppy performance. Due to great flexibility in choosing intercropping cultivars, seeding dates and densities, intercropping poppy can a promising cultivation strategy for poppy in the future.

Supplementary Materials: The following are available online at https:/ /www.mdpi.com/article/10 .3390 /agronomy11050948/s1, Figure S1: Sowing pattern of poppy and its intercropping partners at Campus Klein-Altendof 2019 and 2020, Table S1: Correspondence between Day of Year and BBCH stages; Table S2: Barley yields from sole cropping of three different seeding densities and intercropped with poppy at Campus Klein-Altendorf 2018-2020, Table S3: Dry matter $\left(\mathrm{g} \mathrm{m}^{-2}\right)$ of poppy, white clover and spring barley at Campus Klein-Altendorf 2018, Table S4: Dry matter $\left(\mathrm{g} \mathrm{m}^{-2}\right)$ of poppy, white clover and spring barley at Campus Klein-Altendorf 2019, Table S5: Dry matter $\left(\mathrm{g} \mathrm{m}^{-2}\right)$ of 
poppy, white clover and spring barley at Campus Klein-Altendorf 2020, Table S6: Leaf Area Indices of spring barley as sole crop sown at three different seeding densities and intercropped with poppy at Campus Klein-Altendorf 2019 and 2020, Table S7: Leaf Area Indices of white clover as sole crop sown at two different seeding dates and intercropped with poppy at Campus Klein-Altendorf 2019 and 2020, Table S8: Nitrogen content (\%) in the dry biomass of poppy, white clover and spring barley at Campus Klein-Altendorf 2018, Table S9: Nitrogen content (\%) in the dry biomass of poppy, white clover and spring barley at Campus Klein-Altendorf 2019, Table S10: Nitrogen content (\%) in the dry biomass of poppy, white clover and spring barley at Campus Klein-Altendorf 2020.

Author Contributions: Conceptualization, R.P., H.B. and K.L.; methodology, K.L., H.B.; validation, K.L.; formal analysis, K.L.; investigation, K.L.; resources, R.P.; data curation, K.L.; writing-original draft preparation, K.L.; writing-review and editing, K.L., H.B., T.K. and T.D.; visualization, K.L.; supervision, R.P.; project administration, R.P. and H.B.; funding acquisition, R.P. and H.B. All authors have read and agreed to the published version of the manuscript.

Funding: This research was funded by Deutsche Bundesstiftung Umwelt (DBU), project "Speisemohn im Ökologischen Landbau“, grant number 33936/01.

Institutional Review Board Statement: Not applicable.

Informed Consent Statement: Not applicable.

Data Availability Statement: The data presented in this study are available in the supplementary material. Additional raw data are available on request from the corresponding author.

Acknowledgments: We thank Charlotte Hubert and the team of Campus Klein-Altendorf for support in the experimental work.

Conflicts of Interest: The authors declare no conflict of interest. The funders had no role in the design of the study; in the collection, analyses, or interpretation of data; in the writing of the manuscript, or in the decision to publish the results.

\section{References}

1. Lithourgidis, A.S.; Dordas, C.A.; Damalas, C.A.; Vlachostergios, D.N. Annual intercrops: An alternative pathway for sustainable agriculture. Aust. J. Crop Sci. 2011, 5, 396-410.

2. Brooker, R.W.; Bennett, A.E.; Cong, W.-F.; Daniell, T.J.; George, T.S.; Hallett, P.D.; Hawes, C.; Iannetta, P.P.M.; Jones, H.G.; Karley, A.J.; et al. Improving intercropping: A synthesis of research in agronomy, plant physiology and ecology. New Phytol. 2015, 206, 107-117. [CrossRef] [PubMed]

3. Liebmann, M.; Dyck, E. Crop Rotation and Intercropping Strategies for Weed Management. Ecol. Appl. 1993, 3, 92-122. [CrossRef] [PubMed]

4. Vandermeer, J.H. The Ecology of Intercropping; Cambridge University Press: Cambridge, UK, 2012; ISBN 9780521345927.

5. Kugbe, X.J.; Yaro, R.N.; Soyel, J.K.; Kofi, E.S.; Ghaney, P. Role of Intercropping in Modern Agriculture and Sustainability: A Review. Br. J. Sci. 2018, 16, 67-75.

6. Banik, P.; Midya, A.; Sarkar, B.K.; Ghose, S.S. Wheat and chickpea intercropping systems in an additive series experiment: Advantages and weed smothering. Eur. J. Agron. 2006, 24, 325-332. [CrossRef]

7. Fukai, S.; Trenbath, B.R. Processes determining intercrop productivity and yields of component crops. Field Crop. Res. 1993, 34, 247-271. [CrossRef]

8. Szumigalski, A.; van Acker, R. Weed suppression and crop production in annual intercrops. Weed Sci. 2005, 53, 813-825. [CrossRef]

9. Willey, R.W. Resource Use in Intercropping Systems. Agric. Water Manag. 1990, 17, 215-231. [CrossRef]

10. Szumigalski, A.R.; van Acker, R.C. Nitrogen Yield and Land Use Efficiency in Annual Sole Crops and Intercrops. Agron. J. 2006, 98, 1030. [CrossRef]

11. Bybee-Finley, K.A.; Ryan, M. Advancing Intercropping Research and Practices in Industrialized Agricultural Landscapes. Agriculture 2018, 8, 80. [CrossRef]

12. Yu, Y.; Stomph, T.-J.; Makowski, D.; van der Werf, W. Temporal niche differentiation increases the land equivalent ratio of annual intercrops: A meta-analysis. Field Crop. Res. 2015, 184, 133-144. [CrossRef]

13. Paulsen, H.M.; Schochow, M.; Ulber, B.; Kühne, S.; Rahmann, G. Mixed cropping systems for biological control of weeds and pests in organic oilseed crops. Asp. Appl. Biol. 2006, 79, 215-219.

14. Lanini, W.T.; Orloff, S.B.; Vargas, R.N.; Orr, J.P.; Marble, V.L.; Grattan, S.R. Oat Companion Crop Seeding Rate Effect on Alfalfa Establishment, Yield, and Weed Control. Agron. J. 1991, 83, 330-333. [CrossRef]

15. Kraska, P.; Andruszczak, S.; Kwiecińska-Poppe, E.; Staniak, M.; Różyło, K.; Rusecki, H. Supporting Crop and Different Row Spacing as Factors Influencing Weed Infestation in Lentil Crop and Seed Yield under Organic Farming Conditions. Agronomy 2020, 10, 9. [CrossRef] 
16. Hauggaard-Nielsen, H.; Ambus, P.; Jensen, E.S. Interspecific competition, $\mathrm{N}$ use and interference with weeds in pea-barley intercropping. Field Crop. Res. 2001, 70, 101-109. [CrossRef]

17. Mohler, C.L.; Liebmann, M. Weed Productivity and Composition in Sole Crops and Intercrops of Barley and Field Pea. J. Appl. Ecol. 1987, 24, 685-699. [CrossRef]

18. Corre-Hellou, G.; Dibet, A.; Hauggaard-Nielsen, H.; Crozat, Y.; Gooding, M.; Ambus, P.; Dahlmann, C.; von Fragstein, P.; Pristeri, A.; Monti, M.; et al. The competitive ability of pea-barley intercrops against weeds and the interactions with crop productivity and soil N availability. Field Crop. Res. 2011, 122, 264-272. [CrossRef]

19. Carton, N.; Naudin, C.; Piva, G.; Corre-Hellou, G. Intercropping Winter Lupin and Triticale Increases Weed Suppression and Total Yield. Agriculture 2020, 10, 316. [CrossRef]

20. Elsalahy, H.; Döring, T.; Bellingraht-Kimura, S.; Arends, D. Weed Suppression in Only-Legume Cover Crop Mixtures. Agronomy 2019, 9, 648. [CrossRef]

21. Frick, C.; Hebeisen, T. Mohn als alternative Ölpflanze. Agrar. Schweiz 2005, 12, 4-9.

22. Hiltbrunner, J.; Herzog, C.; Luginbühl, C.; Hebeisen, T. Sorten- und Anbauversuche mit winterhartem Mohn. Agrar. Schweiz 2014, $5,280-285$.

23. Tóth, K.; Blazsek, K.; Reisinger, P.; Pinke, G. Weed flora and historical review of weed control technologies of poppy crops. Magy. Gyomkutatás Technol. 2013, 19, 3-16.

24. Baser, K.H.C.; Arslan, N. Opium Poppy (Papaver somniferum). In Medicinal and Aromatic Plants of the Middle-East; Yaniv, Z., Dudai, N., Eds.; Springer: Dordrecht, The Netherlands, 2014; pp. 305-332. ISBN 978-94-017-9275-2.

25. Yin, W.; Chai, Q.; Zhao, C.; Yu, A.; Fan, Z.; Hu, F.; Fan, H.; Guo, Y.; Coulter, J.A. Water utilization in intercropping: A review. Agric. Water Manag. 2020, 241, 106335. [CrossRef]

26. Rao, M.R.; Willey, R.W. Evaluation of Yield Stability in Intercropping: Studies on Sorghum/Pigeonpea. Exp. Agric. 1980, 16, 105-116. [CrossRef]

27. den Hollander, N.G.; Bastiaans, L.; Kropff, M.J. Clover as a cover crop for weed suppression in an intercropping design. Eur. J. Agron. 2007, 26, 104-112. [CrossRef]

28. Meier, U. Growth Stages of Mono- and Dicotyledonous Plants: BBCH Monograph; Open Agrar Repositorium: Quedlinburg, Germany, 2018. [CrossRef]

29. Mead, R.; Willey, R.W. The Concept of a 'Land Equivalent Ratio' and Advantages in Yields from Intercropping. Exp. Agric. 1980, 16, 217-228. [CrossRef]

30. Food and Agricultural Organization of the United Nations. FAOSTAT Crop Data Poppy Seed. Available online: http://www.fao. org/faostat/en/\#data/QC (accessed on 17 May 2020).

31. Gerhards, R. Weed Suppression Ability and Yield Impact of Living Mulch in Cereal Crops. Agriculture 2018, 8, 39. [CrossRef]

32. Vánová, M.; Palík, S.; Hajslová, J.; Buresová, I. Grain quality and yield of spring barley in field trials under variable growing conditions. Plant Soil Environ. 2006, 52, 211-219. [CrossRef]

33. Povilaitis, V.; Lazauskas, S.; Antanaitis, Š.; Feizienè, D.; Feiza, V.; Tilvikienè, V. Relationship between spring barley productivity and growing management in Lithuania's lowland. Acta Agric. Scand. Sect. B Soil Plant Sci. 2018, 68, 86-95. [CrossRef]

34. Brooker, R.W.; Maestre, F.T.; Callaway, R.M.; Lortie, C.L.; Cavieres, L.A.; Kunstler, G.; Liancourt, P.; Tielbörger, K.; Travis, J.; Anthelme, F.; et al. Facilitation in Plant Communities: The Past, the Present, and the Future. J. Ecol. 2008, 96, 18-34. [CrossRef]

35. Blume, H.-P.; Brümmer, G.W.; Horn, R.; Kandeler, E.; Kögel-Knabner, I. Lehrbuch der Bodenkunde, 16. Auflage; Spektrum Akademischer: Heidelberg, Germany, 2010; ISBN 9783827422514.

36. Statistisches Bundesamt BMEL. Getreideernte 2020-2. vorläufiges Ergebnis. MBT-0112060-0000. Available online: https: / / bmel-statistik.de/fileadmin/daten/MBT-0112060-0000.xlsx (accessed on 9 May 2021).

37. Andersen, M.K.; Hauggaard-Nielsen, H.; Ambus, P.; Steen, E. Biomass production, symbiotic nitrogen fixation and inorganic N use in dual and tri-component annual intercrops. Plant Soil 2004, 266, 273-287. [CrossRef]

38. Yadav, R.L.; Mohan, R.; Singh, R.; Verma, R.K. The effect of application of nitrogen fertilizer on the growth of opium poppy in north central India. J. Agric. Sci. 1984, 102, 361-366. [CrossRef]

39. Edelbauer, A.; Stangl, J. Nährstoffentzug durch den Waldviertler Graumohn (Papaver somniferum L.) im Verlauf der Vegetationszeit. Die Bodenkult. 1993, 44, 15-27.

40. Chizzola, R.; Dobos, G. Ertrag und Nährstoffentzug von Winter- und Sommermohnsorten (Papaver somniferum L.). Z. Für Arznei Und Gewürzpflanzen 2007, 12, 30-36.

41. Lošák, T.; Richter, R. Split nitrogen doses and their efficiency in poppy (Papaver somniferum L.) nutrition. PlantSoil Environ. 2004, 50, 484-488. [CrossRef]

42. Liebmann, M. Weed Suppression in Intercropping Systems: Experiments with Barley, pea, and Mustard; University of California: Berkeley, CA, USA, 1986.

43. Webster, F. Oats: Chemistry and Technology, 2nd ed.; Elsevier Science \& Technology: Atlanta, GA, USA; ProQuest: Ann Arbor, MI, USA, 2016; ISBN 9780128104521. 